\title{
PENGARUH PERKEMBANGAN INDUSTRI PENGECORAN LOGAM SKALA BESAR DAN SEDANG YANG TERAGLOMERASI TERHADAP PERUBAHAN GUNA LAHAN DI KECAMATAN CEPER KABUPATEN KLATEN
}

\author{
Nur Lutfi Rizky Tantowi', Soedwiwahjono', Ana Hardiana1 \\ 1 Program Studi Perencanaan Wilayah dan Kota Fakultas Teknik Universitas Sebelas Maret Surakarta
}

\begin{abstract}
Abstrak
Dewasa ini kemajuan ilmu pengetahuan dan teknologi memicu pertumbuhan yang pesat pada segala aspek kehidupan salah satu adalah aspek industri. Industri skala besar dan sedang setiap tahunnya mengalami perkembangan, hal tersebut juga terjadi pada industri pengecoran logam skala besar dan sedang yang berada di Kecamatan Ceper Kabupaten Klaten selama kurun waktu tahun 2006 hingga tahun 2016. Industri-industri pengecoran logam tersebut memiliki lokasi yang berdekatan sebagai salah satu bentuk untuk mendapatkan keuntungan aglomerasi. Akan tetapi, industri yang mengalami peningkatan tersebut berpengaruh terhadap sekitarnya, salah satu pengaruh yang ditimbulkan adalah terhadap guna lahan di sekitarnya yang mengalami perubahan. Berdasarkan permasalahan tersebut maka tujuan penelitian ini adalah mengetahui pengaruh perkembangan industri pengecoran logam skala besar dan sedang yang teraglomerasi terhadap perubahan guna lahan. Metode penelitian yang digunakan adalah deskriptif kuantitatif. Sementara jenis penelitian ini adalah penelitian deduktif. Metode analisis yang digunakan adalah analisis skoring dengan membandingkan kondisi awal penelitian dengan kondisi akhir penelitian. Berdasarkan data yang diperoleh didapatkan bahwa industri pengecoran logam skala besar dan sedang yang teraglomerasi mengalami perkembangan, sementara guna lahan di wilayah tersebut juga ikut mengalami perubahan. Karena sama-sama mengalami perkembangan/perubahan maka hubungan antara perkembangan industri dan perubahan guna lahan dapat disebut sebagai hubungan yang lurus, hal tersebut dapat diketahui dari perkembangan industri pengecoran logam skala besar dan sedang yang teraglomerasi yang berpengaruh tinggi terhadap perubahan guna lahan.
\end{abstract}

Kata kunci: aglomerasi; guna lahan; perkembangan industri

\begin{abstract}
Nowadays, the advance of science and technology is making influence to the growth of every aspect in our lives, one of which is the industries. Each year, medium and large scale industries keep growing and the metal foundry industries in Kecamatan Ceper Kabupaten Klaten during 2006-2016 are no exception. These industries are located close to each other as a means of getting the perks of agglomeration. Consequently, the growing industries had caused much impact to its surroundings, for instance, land use changes in the area which is a result of the industrial development. Based on this problem, the research purpose is to discover the impact of medium and large scale metal foundry industries on land use changes in Kecamatan Ceper Kabupaten Klaten. The method used in this research is descriptive qualitative. This research can be classified as deductive research. Analysis method used in this research is scoring analysis by comparing conditions at the beginning and the end of research. From the data obtained during research, it was known that land use changes in the area happened as the medium and large scale industries were making growth with their development. Since both industries and land use changes were in line, it is concluded that the relationship between these two variables was directly proportional, and it was shown from the fact that medium and large scale metal foundry industries had heavily impacted land use changes in the area.
\end{abstract}

Keywords: agglomeration; industrial development; land use

\section{PENDAHULUAN}

Indonesia dikenal sebagai negara agraris, yaitu negara yang mengandalkan sektor pertanian sebagai mata pencaharian utama penduduknya. Akan tetapi, untuk perkembangan zaman membuat keberadaan sektor lain tidak 
dapat dipandang sebelah mata, seperti sektor industri. Hal tersebut juga terjadi di Kecamatan Ceper Kabupaten Klaten, wilayah tersebut dikenal sebagai tempat industri pengecoran logam terbesar di Indonesia, ditandai dengan industri pengecoran logam skala besar dan sedang di wilayah tersebut yang tiap tahunnya mengalami peningkatan. Lokasi industri pengecoran logam tersebut cenderung memiliki lokasi yang berdekatan karena dapat memberikan banyak keuntungan atau yang sering disebut sebagai aglomerasi. Penghematan aglomerasi merupakan berkumpulnya berbagai jenis industri dapat menimbulkan penghematan eksternal. Selain itu, aglomerasi juga merupakan salah satu faktor untuk menurunkan biaya terutama external economies, industri berlokasi secara bersama dalam memanfaatkan fasilitas yang ada (Djojodipuro, 1992).

Perkembangan industri tentunya memiliki dampak bagi lingkungan di sekitarnya salah satunya berdampak terhadap perubahan guna lahan. Kehadiran industri menyebabkan perubahan-perubahan sosial-ekonomi seperti perubahan kepemilikan dan pemanfaatan lahan. Perubahan penggunaan lahan yang terjadi akan berpengaruh terhadap pola penggunaan lahan dan pola jaringan jalan yang merupakan elemen penyusun struktur ruang (Sunarjan, 1991). Sementara pendapat lain mengatakan bahwa keberadaan industri berpengaruh terhadap perubahan lahan sekitarnya, hal tersebut ditandai dengan munculnya bangunan-bangunan baru di sekitar jalan-jalan utama yang dekat dengan industri tersebut, selain itu harga tanah di sekitar industri (Fatikawati dan Muktiali, 2015). Guna lahan di Kecamatan Ceper Kabupaten Klaten juga mengalami perubahan ditandai dengan menjadi kecamatan yang mengalami perubahan guna lahan terbesar di kabupaten yaitu mengalami perubahan lahan seluas 8,78 Ha dari lahan pertanian menjadi lahan perumahan dan lahan industri (Kabupaten Klaten Dalam Angka, 2016). Berdasarkan penjelasan di atas dapat disimpulkan bahwa rumusan masalah pada penelitian ini adalah bagaimana pengaruh perkembangan industri pengecoran logam skala besar dan sedang yang teraglomerasi terhadap perubahan guna lahan.

Penelitian ini bertujuan untuk mengetahui pengaruh perkembangan industri pengecoran logam skala besar dan sedang yang teraglomerasi terhadap perubahan guna lahan. Berdasarkan tujuan penelitian tersebut terdapat 3 sasaran pada penelitian ini yaitu identifikasi karakteristik perkembangan industri pengecoran logam skala besar dan sedang yang teraglomerasi di wilayah penelitian, identifikasi karakteristik perubahan guna lahan di wilayah penelitian dan analisis tingkat pengaruh perkembangan industri pengecoran logam skala besar dan sedang yang teraglomerasi terhadap perubahan guna lahan di wilayah penelitian.Ruang lingkup wilayah penelitian ini adalah desa-desa yang terdapat industri pengecoran logam skala besar dan sedang yang lokasi berdekatan yaitu Desa Ceper, Desa Klepu, Desa Kurung, Desa Ngawonggo dan Desa Tegalrejo. Ruang lingkup waktu penelitian ini selama kurun waktu 10 tahun yang dimulai sejak tahun 2006 hingga tahun 2016.

\section{KAJIAN TEORI}

Industri merupakan seluruh bentuk dari kegiatan ekonomi yang mengolah bahan baku dan atau memanfaatkan sumber daya industri, sehingga dapat menghasilkan barang yang memiliki nilai tambah atau manfaat yang lebih tinggi, termasuk juga jasa industri (Undang-Undang No. 3 Tahun 2014 tentang Perindustrian). Industri skala besar dan sedang adalah industri yang memiliki jumlah tenaga kerja lebih dari 19 tenaga kerja (Industri Skala Besar BPS). Dalam menentukan lokasi industri perlu mempertimbangkan beberapa alasan. Usaha meminimalkan biaya, maka suatu industri berusaha untuk memilih lokasi yang tepat. Salah satu langkah yang ditempuh adalah dengan memilih lokasi yang berdekatan dengan industri lain atau yang disebut dengan aglomerasi (Djojodipuro,1992).

Perkembangan industri ditandai dengan peningkatan jumlah industri yaitu penambahan jumlah industri dari awal tahun hingga akhir tahun, peningkatan jumlah tenaga kerja yaitu meningkatnya jumlah orang yang bekerja dalam menghasilkan barang dan/atau jasa serta peningkatan luas lahan industri yaitu meningkatnya luas lahan industri dari awal tahun hingga akhir tahun, perkembangan industri yang signifikan apabila mengalami peningkatan sebesar $40 \%$ dibandingkan dengan kondisi awal (Abdullah, 2010). Keberadaan industri menyebabkan dampak bagi wilayah sekitarnya, salah satu dampak yang ditimbulkan adalah dampak terhadap perubahan kondisi fisik/perubahan guna lahan, selain itu berdampak terhadap kondisi lingkungan dan kondisi ekonomi (Sari dan Rahayu, 2014). Perubahan guna lahan dapat diidentifikasi dari perubahan jenis lahan serta perubahan intensitas lahan (Baja, 2012). Sementara perubahan intensitas penggunaan lahan mencakup koefisien dasar bangunan (KDB) dengan menghitung persentase perbandingan antara seluruh luas lantai dasar dengan luas wilayah sementara koefisien lantai bangunan (KLB) dengan menghitung persentase perbandingan antara seluruh luas lantai bangunan dengan luas wilayah (Muta'ali, 2012). Perubahan intensitas lahan yang diakibatkan oleh perkembangan industri besar dan sedang yang teraglomerasi dikatakan tinggi apabila persentase perubahannya lebih dari 4\% dari kondisi awal (Ardian, 2015). Selain itu perubahan guna lahan juga dapat mempengaruhi perubahan pola penggunaan lahan di wilayah sekitarnya (Colby dalam Yunus, 1999). Terdapat tiga pola penggunaan lahan yaitu pola konsentis, memanjang dan meloncat (Yunus, 1999). 


\section{METODE PENELITIAN}

Penelitian ini menggunakan metode penelitian deskriptif kuantitatif. Data-data yang digunakan untuk menganalisis penelitian ini menggunakan data sekunder berupa studi literatur serta interpretasi peta dan citra satelit, sementara data primer yang digunakan berupa observasi lapangan dan wawancara. Populasi perkembangan industri dan perubahan guna lahan pada penelitian ini mengambil seluruh wilayah penelitian atau dapat dikatakan dengan istilah purposive sampling. Sementara untuk analisis data penelitian ini disesuaikan dengan sasaran penelitian ini yang terbagi menjadi tiga tahapan, yaitu sebagai berikut.

I. Analisis Perkembangan Industri Pengecoran Logam Skala Besar dan Sedang yang Teraglomerasi

Terdapat tiga analisis dalam mengukur perkembangan industri di wilayah penelitian yaitu peningkatan jumlah industri, peningkatan jumlah tenaga kerja serta penngkatan luas lahan industri. Analisis-analisis tersebut menggunakan analisis deskriptif skoring.

Tabel 1. Analisis Perkembangan Industri Pengecoran Logam Skala Besar dan Sedang yang Teraglomerasi

\begin{tabular}{|c|c|c|c|c|}
\hline Analisis & Input & Proses & Output & Skoring dan Tolak Ukur \\
\hline $\begin{array}{l}\text { Peningkatan } \\
\text { Jumlah Industri }\end{array}$ & $\begin{array}{c}\text { Jumlah industri } \\
\text { pengecoran logam skala } \\
\text { besar dan sedang pada } \\
\text { tahun 2006-2016 }\end{array}$ & \multirow{3}{*}{$\begin{array}{l}\mathrm{p}=\frac{\mathrm{b}-\mathrm{a}}{a} \cdot 100 \%, \text { dengan } \\
\mathrm{p}: \text { Persentase } \\
\quad \text { peningkatan } \\
\mathrm{b}: \text { Nilai pada tahun } 2016 \\
\mathrm{a}: \text { Nilai pada tahun } 2006\end{array}$} & $\begin{array}{l}\text { Persentase peningkatan } \\
\text { jumlah industri } \\
\text { pengecoran logam skala } \\
\text { besar dan sedang }\end{array}$ & \multirow{3}{*}{ 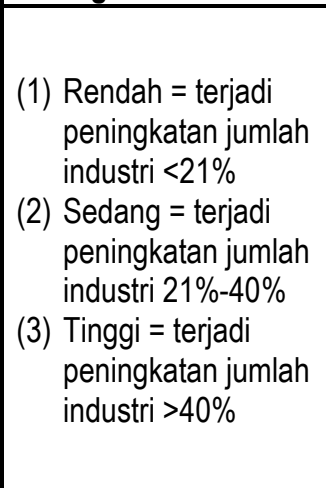 } \\
\hline $\begin{array}{c}\text { Peningkatan } \\
\text { Jumlah Tenaga } \\
\text { Kerja }\end{array}$ & $\begin{array}{l}\text { Jumlah tenaga kerja } \\
\text { industri pengecoran logam } \\
\text { skala besar dan sedang } \\
\text { pada tahun } 2006-2016\end{array}$ & & $\begin{array}{l}\text { Persentase peningkatan } \\
\text { jumlah tenaga kerja } \\
\text { industri pengecoran logam } \\
\text { skala besar dan sedang }\end{array}$ & \\
\hline $\begin{array}{l}\text { Peningkatan } \\
\text { Luas Lahan } \\
\text { Industri }\end{array}$ & $\begin{array}{c}\text { Jumlah luasan lahan } \\
\text { industri pengecoran logam } \\
\text { skala besar dan sedang } \\
\text { pada tahun } 2006-2016\end{array}$ & & $\begin{array}{l}\text { Persentase peningkatan } \\
\text { luasan lahan industri } \\
\text { pengecoran logam skala } \\
\text { besar dan sedang }\end{array}$ & \\
\hline
\end{tabular}

Sumber: Abdullah dan Peneliti, 2017

Selanjutnya untuk mengetahui perkembangan industri di wilayah penelitian dilakukan dengan menghitung jumlah masing-masing nilai yang didapat selanjutnya di cari nilai rata-ratanya, kemudian di cocokkan dengan klasifikasi sebagai berikut, peningkatan rendah apabila mendapat nilai rata-rata 1,00-1,66; peningkatan sedang apabila mendapat nilai rata-rata 1,67-2,32 sementara peningkatan tinggi apabila mendapatkan nilai rata-rata 2,33-3,00.

\section{Analisis Perubahan Guna Lahan}

Terdapat tiga analisis dalam mengukur perubahan guna lahan di wilayah penelitian yaitu perubahan jenis lahan, perubahan intensitas lahan dan perubahan pola penggunaan lahan. Analisis-analisis tersebut menggunakan analisis deskriptif skoring.

Tabel 2. Analisis Perubahan Guna Lahan

\begin{tabular}{|c|c|c|c|c|c|}
\hline \multicolumn{2}{|c|}{ Analisis } & Input & Proses & Output & Skoring dan Tolak Ukur \\
\hline $\begin{array}{c}\text { Perubahan Jenis } \\
\text { Lahan }\end{array}$ & $\begin{array}{c}\text { Luas masing- } \\
\text { masing jenis lahan } \\
\text { pada tahun 2006- }\end{array}$ & & $\begin{array}{c}\text { Persentase perubahan } \\
\text { lahan terbangun dan } \\
\text { lahan tidak terbangun } \\
\text { jenis lahan }\end{array}$ & (1) Rendah = terjadi \\
perubahan jenis \\
lahan $<2 \%$ \\
$\begin{array}{c}\text { Perubahan } \\
\text { Intensitas } \\
\text { Lahan }\end{array}$
\end{tabular}




\begin{tabular}{|c|c|c|c|c|}
\hline Perubahan Pola & $\begin{array}{c}\text { Peta guna lahan } \\
\text { penga tahun 2006- } \\
2016\end{array}$ & $\begin{array}{c}\text { Deskriptif dengan membandingkan } \\
\text { perubahan pola penggunaan lahan } \\
\text { pada tahun 2006 dan tahun 2016 }\end{array}$ & $\begin{array}{c}\text { Perubahan pola } \\
\text { penggunaan lahan }\end{array}$ & $\begin{array}{l}\text { (1) Rendah = meloncat } \\
\text { (2) Sedang = memanjang } \\
\text { (3) Tinggi = konsentris }\end{array}$ \\
\hline
\end{tabular}

Sumber: Ardian, Yunus dan Peneliti, 2017

III. Analisis Tingkat Pengaruh Perkembangan Industri Pengecoran Logam Skala Besar dan Sedang yang Teraglomerasi terhadap Perubahan Guna Lahan

Teknik analisis yang digunakan adalah teknik analisis deskriptif kuantitatif. Teknik analisis statistik deskripsi adalah analisis data dengan menggunakan cara mendeskripsikan atau menggambarkan data yang telah diperoleh/terkumpul sebagaimana adanya tanpa bermaksud membuat kesimpulan yang berlaku umum atau generalisasi (Sugiyono, 2014). Data yang digunakan adalah data karakteristik perkembangan industri pengecoran logam skala besar dan sedang yang teraglomerasi serta data karakteristik perubahan guna lahan di wilayah penelitian.

Perkembangan industri pengecoran logam skala besar dan sedang yang teraglomerasi memiliki hubungan yang erat terhadap perubahan guna lahan. Pertumbuhan ekonomi yang ditandai dengan bertambahnya industri merupakan salah satu faktor yang menyebabkan terjadinya perubahan guna lahan di sekitarnya. Sehingga dapat diketahui bahwa perkembangan industri akan mempengaruhi perubahan guna lahan (Von Thunen dalam Nugroho dan Dahuri, 2012) serta Jayadinata, 1999), maka dapat dikatakan bahwa perkembangan industri memiliki hubungan yang lurus dengan perubahan guna lahan di sekitarnya. Hal tersebut yang dijadikan dasar untuk analisis pengaruh perkembangan industri terhadap perubahan guna lahan. Berikut merupakan kurva pengaruh perkembangan industri pengecoran logam skala besar dan sedang terhadap perubahan guna lahan.

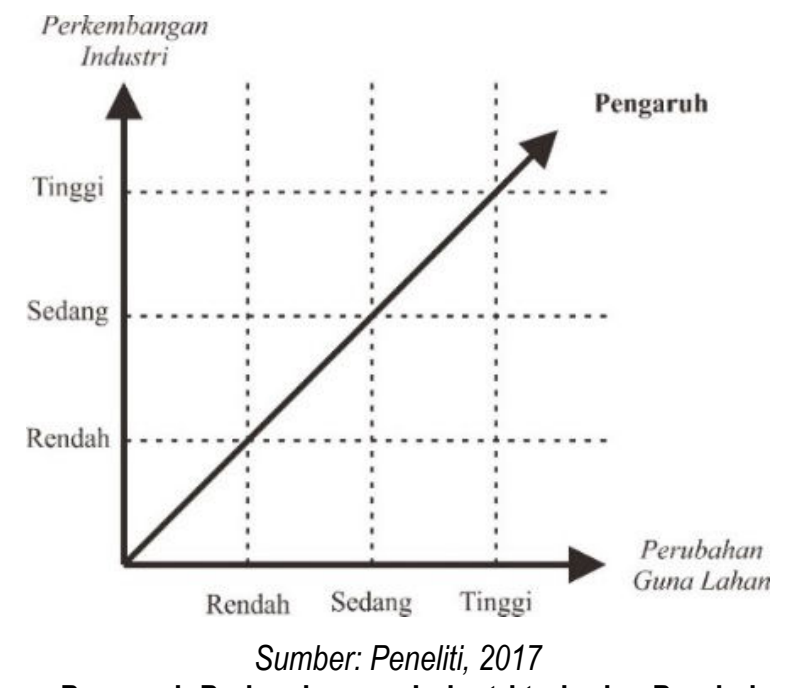

Gambar 1. Kurva Pengaruh Perkembangan Industri terhadap Perubahan Guna Lahan

Pada analisis ini akan membahas pengaruh pengaruh perkembangan industri pengecoran logam skala besar dan sedang yang teraglomerasi terhadap masing-masing aspek perubahan guna lahan yang terdiri dari analisis pengaruh perkembangan industri pengecoran logam skala besar dan sedang yang teraglomerasi terhadap perubahan jenis lahan, pengaruh perkembangan industri pengecoran logam skala besar dan sedang yang teraglomerasi terhadap perubahan intensitas lahan yang membahas mengenai perubahan koefisien dasar bangunan (KDB) serta perubahan koefisien lantai bangunan (KLB) dan analisis pengaruh perkembangan industri pengecoran logam skala besar dan sedang yang teraglomerasi terhadap perubahan pola penggunaan lahan di wilayah penelitian. 


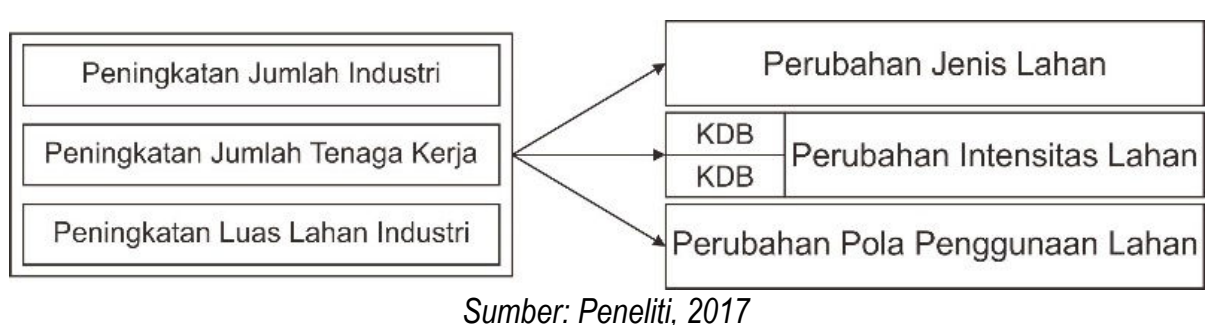

Sumber: Peneliti, 2017

Gambar 2. Analisis Pengaruh Perkembangan Industri Pengecoran Logam Skala Besar dan Sedang yang Teraglomerasi terhadap Variabel Perubahan Guna Lahan

Masing-masing analisis perkembangan industri pengecoran logam skala besar dan sedang yang teraglomerasi terhadap aspek-aspek perubahan guna lahan akan menghasilkan pengaruh antara keduanya, dari pengaruh tersebut selanjutnya diberikan nilai yaitu nilai 3 untuk pengaruh tinggi, nilai 2 untuk pengaruh sedang dan nilai 1 untuk pengaruh rendah. Sementara untuk analisis perkembangan industri terhadap perubahan intensitas lahan dilakukan perhitungan dulu dengan cara menghitung nilai rata-rata dari KDB maupun KLB, kemudian dicocokkan dengan klasifikasi tersebut. Selanjutnya untuk mengetahui tingkat pengaruh perkembangan industri pengecoran logam skala besar dan sedang yang teraglomerasi terhadap perubahan guna lahan dilakukan dengan penjumlahan nilai masing-masing analisis selanjutnya dicocokkan dengan klasifikasi berikut. Pengaruh rendah apabila mendapat nilai keseluruhan 3,0-5,0; pengaruh sedang apabila mendapat nilai keseluruhan 5,1-7,0 serta pengaruh tinggi apabila mendapat nilai 7,1-9,0.

\section{HASIL DAN PEMBAHASAN}

Berdasarkan tujuan penelitian ini yaitu mengetahui pengaruh perkembangan industri pengecoran logam skala besar dan sedang yang teraglomerasi terhadap perubahan guna lahan di wilayah sekitarnya didapatkan tiga sasaran untuk menjawab tujuan penelitian tersebut yaitu analisis perkembangan industri pengecoran logam skala besar dan sedang yang teraglomerasi, analisis perubahan guna lahan serta analisis pengaruh perkembangan industri pengecoran logam skala besar dan sedang yang teraglomerasi terhadap guna lahan di wilayah penelitian. Berikut merupakan hasil dan pembahasan masing-masing sasaran tersebut.

I. Analisis Perkembangan Industri Pengecoran Logam Skala Besar dan Sedang yang Teraglomerasi di Wilayah Penelitian

Analisis ini akan membahas mengenai peningkatan jumlah industri, peningkatan jumlah tenaga kerja dan peningkatan luas lahan industri di wilayah penelitian.

Tabel 3. Analisis Perkembangan Industri Pengecoran Logam Skala Besar dan Sedang yang Teraglomerasi di Wilayah Penelitian

\begin{tabular}{|l|c|c|c|c|c|}
\hline \multicolumn{1}{|c|}{ Analisis } & $\mathbf{2 0 0 6}$ & $\mathbf{2 0 1 6}$ & Perubahan & $\begin{array}{c}\text { Persentase } \\
\text { Perubahan }\end{array}$ & Skoring \\
\hline Peningkatan Jumlah Industri & 35 Industri & 41 Industri & 6 Industri & $14,29 \%$ & 1 (Rendah) \\
\hline Peningkatan Jumlah Tenaga Kerja & 1.461 orang & 1.830 orang & 367 orang & $25,17 \%$ & 2 (Sedang) \\
\hline Peningkatan Luas Lahan Industri & $26,19 \mathrm{Ha}$ & $35,03 \mathrm{Ha}$ & $8,84 \mathrm{Ha}$ & $33,75 \%$ & 2 (Sedang) \\
\hline \multicolumn{7}{|l|}{} & Jumlah & $\mathbf{5}$ \\
\hline
\end{tabular}

Sumber: Analisis Peneliti, 2017

Dari ketiga pembahasan diatas dapat diketahui bahwa perkembangan industri di wilayah penelitian selama kurun waktu tahun 2006 hingga tahun 2016 mengalami peningkatan sedang, hal tersebut dapat diketahui dari penjumlahan nilai masing-masing pembahasan di atas yang memiliki jumlah keseluruhan nilai yaitu 5 sehingga memiliki nilai rata-rata 1,67 (nilai rata-rata 1,67-2,32).

\section{Analisis Perubahan Guna Lahan di Wilayah Penelitian}

Analisis ini akan membahas mengenai perubahan jenis lahan, perubahan intensitas lahan serta perubahan pola penggunaan lahan di wilayah penelitian.

Tabel 4. Analisis Perubahan Guna Lahan di Wilayah Penelitian

\begin{tabular}{|l|c|c|c|c|c|}
\hline \multicolumn{2}{|c|}{ Analisis } & $\mathbf{2 0 0 6}$ & $\mathbf{2 0 1 6}$ & Persentase Perubahan & Skoring \\
\hline \multicolumn{2}{|l|}{ Perubahan Jenis Lahan } & $40,90 \%$ & $44,08 \%$ & $3,18 \%$ & 2 (Sedang) \\
\hline Perubahan Intensitas Lahan & KDB & $15,62 \%$ & $17,56 \%$ & $1,92 \%$ & 1 (Rendah) \\
\hline
\end{tabular}




\begin{tabular}{|l|c|c|c|c|c|}
\hline & KLB & $16,01 \%$ & $18,33 \%$ & $2,32 \%$ & $2($ Sedang) \\
\hline Perubahan Pola Penggunaan Lahan & Acak & Acak & Tetap Acak & 1 (Rendah) \\
\hline
\end{tabular}

Sumber: Analisis Peneliti, 2017

III. Analisis Tingkat Pengaruh Perkembangan Industri Pengecoran Logam Skala Besar dan Sedang yang Teraglomerasi terhadap Perubahan Guna Lahan

Analisis ini akan membahas pengaruh perkembangan industri skala besar dan sedang yang teraglomerasi terhadap aspek perubahan guna lahan.

- Pengaruh Perkembangan Industri Pengecoran Logam Skala Besar dan Sedang yang Teraglomerasi terhadap Perubahan Jenis Lahan

Perkembangan industri pengecoran logam skala besar dan sedang yang teraglomerasi di wilayah penelitian masuk dalam perkembangan sedang sementara perubahan jenis lahan masuk dalam perubahan sedang. Karena sama-sama memiliki perkembangan/perubahan sedang maka perkembangan industri pengecoran logam skala besar dan sedang yang teraglomerasi berpengaruh tinggi terhadap perubahan jenis lahan di wilayah penelitian selama kurun waktu 10 tahun dan mendapat nilai 3. Keberadaan industri telah mempengaruhi kondisi fisik wilayah sekitarnya, hal tersebut dapat dilihat berdasarkan perubahan penggunaan lahan, kondisi prasarana jalan dan ketersediaan fasilitas umum (Sari dan Rahayu, 2014). Perubahan lahan tersebut salah satu contohnya terjadi dari lahan perumahan menjadi lahan komersial seperti warung makan dan penginapan untuk menunjang aktivitas industri tersebut (Fatikawati dan Muktiali, 2015). Perubahan jenis lahan dari lahan tidak terbangun menjadi lahan terbangun di wilayah penelitian yang mengalami peningkatan. Salah satunya terjadi pada jenis lahan perdagangan dan jasa yang ditandai dengan munculnya penggunaan jenis lahan perdagangan dan jasa baru di wilayah penelitian. Selain itu, perubahan jenis lahan yang diakibatkan oleh perkembangan industri pengecoran logam di wilayah penelitian membuat terjadinya penambahan jenis lahan industri (selain industri pengecoran logam skala besar dan sedang) yang memanfaatkan keuntungan aglomerasi. Jenis lahan perumahan juga mengalami peningkatan, hal ditandai dengan munculnya perumahan formal maupun perumahan informal baru di wilayah penelitian. Jenis lahan sarana umum juga mengalami peningkatan ditandai dengan munculnya sarana pendidikan baru berupa pondok pesantren maupun pendidikan anak usia dini (PAUD) di wilayah penelitian, sementara jenis lahan persawahan mengalami penurunan. Hal tersebut membuktikan bahwa perkembangan industri skala besar dan sedang yang teraglomerasi berpengaruh terhadap perubahan jenis lahan. Berikut merupakan peta pengaruh perkembangan industri pengecoran logam skala besar dan sedang terhadap perubahan jenis lahan 


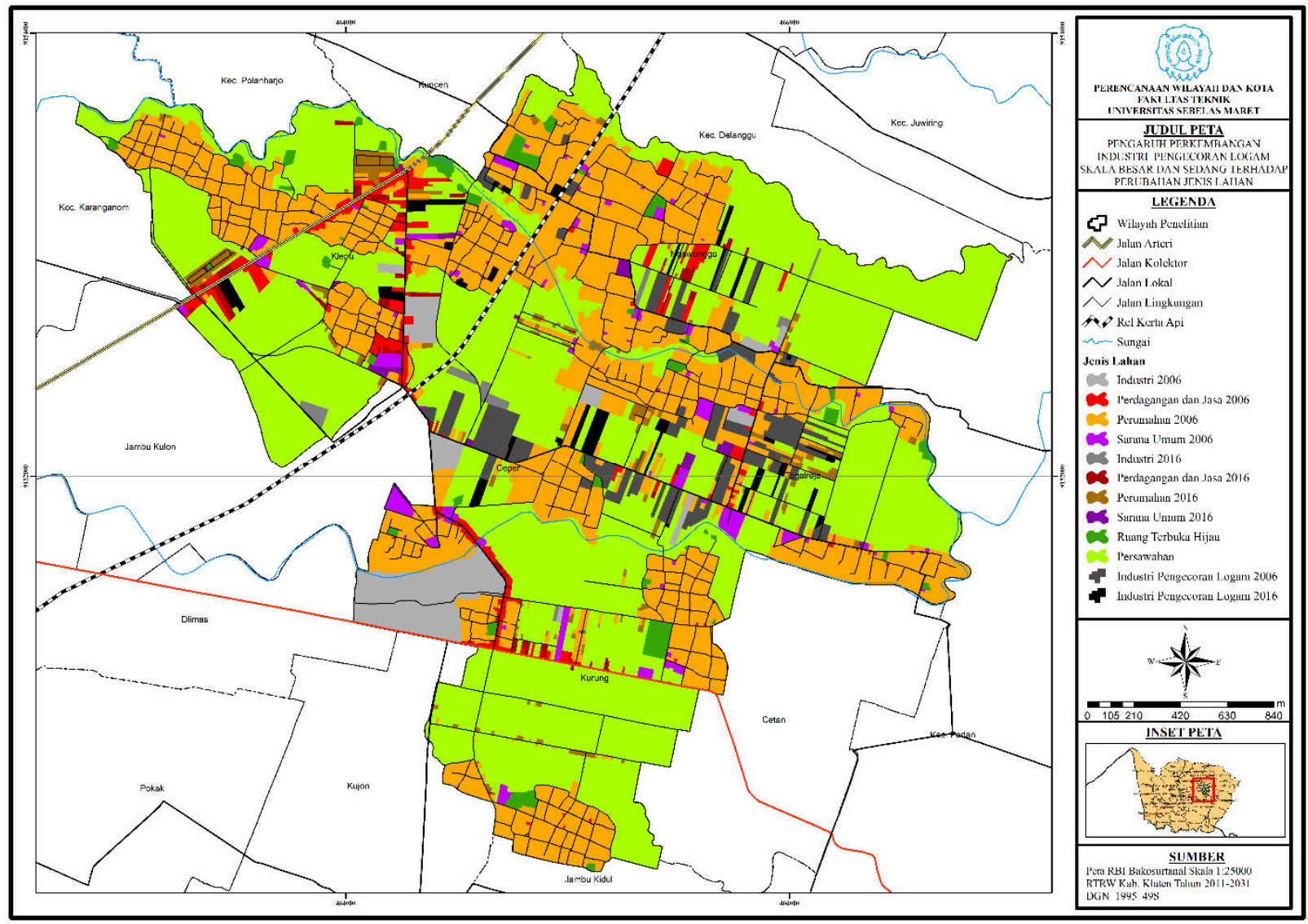

Sumber: Peneliti, 2017

Gambar 3. Peta Pengaruh Perkembangan Industri Pengecoran Logam Skala Besar dan Sedang yang Teraglomerasi terhadap Perubahan Jenis Lahan

- Pengaruh Tingkat Perkembangan Industri Pengecoran Logam Skala Besar dan Sedang yang Teraglomerasi terhadap Perubahan Intensitas Lahan

Pengaruh perkembangan industri pengecoran logam skala besar dan sedang yang teraglomerasi terhadap aspek perubahan intensitas lahan terdiri dari dua bahasan. Pembahasan dari perubahan blok peruntukan atau intensitas lahan dapat dilihat melalui perhitungan perubahan koefisien dasar bangunan (KDB) serta perubahan koefisien lantai bangunan (KLB) (Bakar, 2006). Perkembangan industri dapat menyebabkan perubahan guna lahan dari lahan pertanian ke lahan non-pertanian. Perkembangan industri skala besar dan sedang juga berpengaruh terhadap penambahan intensitas pemanfaatan lahan permukiman yang sudah ada yang berada di kawasan industri (Abdullah 2010). Hal tersebut menunjukkan bahwa perkembangan industri mampu mempengaruhi perubahan pola pemanfaatan lahan di wilayah sekitarnya. Selain itu, keberadaan industri juga berpengaruh terhadap sekitarnya, hal tersebut ditandai dengan munculnya bangunan-bangunan baru di sekitar jalan-jalan utama yang dekat dengan industri tersebut (Fatikawati dan Muktiali, 2015).

Perkembangan industri pengecoran logam skala besar dan sedang yang teraglomerasi di wilayah penelitian masuk dalam perkembangan sedang sementara perubahan koefisien dasar bangunan (KDB) masuk dalam perubahan rendah. Karena hubungan keduanya tidak berjalan lurus maka perkembangan industri pengecoran logam skala besar dan sedang yang teraglomerasi berpengaruh sedang terhadap perubahan koefisien dasar bangunan di wilayah penelitian dan mendapat nilai 2. Hal tersebut dapat terlihat dari koefisien dasar bangunan (KDB) di wilayah penelitian selama kurun waktu 10 tahun rata-rata mengalami perubahan rendah, akan tetapi terdapat juga blok yang mengalami perubahan sedang maupun perubahan tinggi, bahkan terdapat blok yang tidak mengalami perubahan koefisien dasar bangunan (KDB). Seperti pada blok KL6 dan KL8 yang mengalami penambahan bangunan baru yang disebabkan perkembangan industri. Hal tersebut dapat terlihat dari keberadaan industri baru yang berada dekat dengan blok-blok yang mengalami perubahan koefisien dasar bangun (KDB) tinggi. 
Sementara perkembangan industri pengecoran logam skala besar dan sedang yang teraglomerasi di wilayah penelitian masuk dalam perkembangan sedang sementara perubahan koefisien lantai bangunan (KLB) masuk dalam perubahan sedang. Karena sama-sama memiliki perkembangan/perubahan sedang maka perkembangan industri pengecoran logam skala besar dan sedang yang teraglomerasi berpengaruh tingi terhadap perubahan koefisien lantai bangunan (KLB) dan mendapat nilai 3. Hal tersebut dapat terlihat dari Koefisien lantai bangunan (KLB) di wilayah penelitian selama kurun waktu 10 tahun rata-rata mengalami perubahan sedang, akan tetapi terdapat juga blok yang mengalami perubahan sedang maupun perubahan tinggi, bahkan terdapat blok yang tidak mengalami perubahan koefisien lantai bangunan (KLB). Seperti pada blok CP1, KL2 dan KL4 yang mengalai perubahan persentase tinggi yang ditandai dengan munculnya bangunan industri (selain industri pengecoran logam skala besar dan sedang) baru yang memiliki lantai lebih dari 1 karena ingin memanfaatkan keuntungan aglomerasi yang telah tersedia di wilayah penelitian. Hal tersebut terlihat dari blok-blok yang mengalami perubahan koefisien lantai bangunan (KLB) tinggi merupakan blok yang dekat dengan industri pengecoran logam baru. Berikut merupakan peta pengaruh perkembangan industri pengecoran logam skala besar dan sedang terhadap perubahan intensitas lahan (KLB). Berikut merupakan peta pengaruh perkembangan industri pengecoran logam skala besar dan sedang terhadap perubahan intensitas lahan yaitu koefisien dasar bangunan dan koefisien lantai bangunan

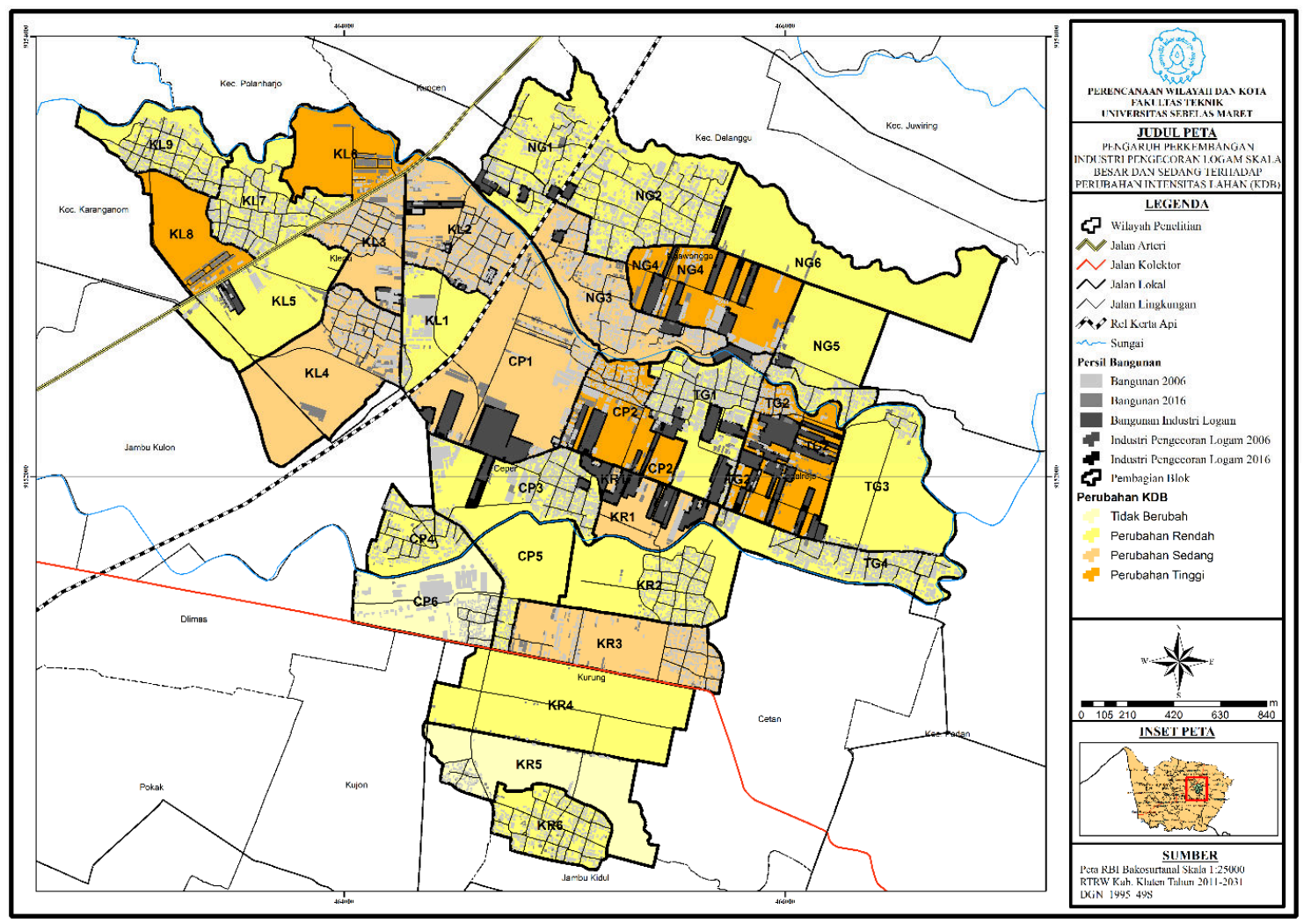

Sumber: Peneliti, 2017

Gambar 4. Peta Pengaruh Perkembangan Industri Pengecoran Logam Skala Besar dan Sedang yang Teraglomerasi terhadap Perubahan Koefisien Dasar Bangunan (KDB) 


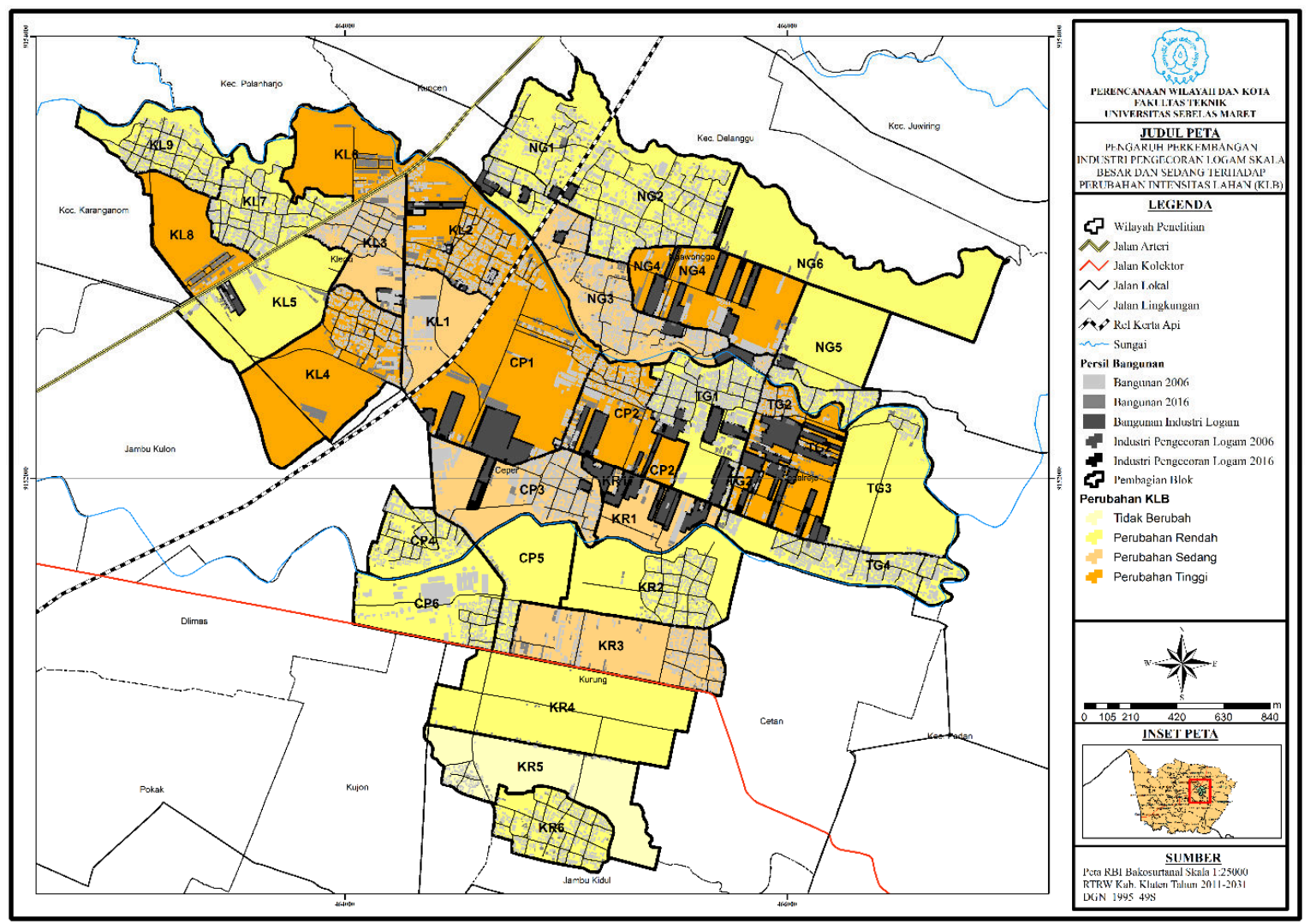

Sumber: Peneliti, 2017

Gambar 5. Peta Pengaruh Perkembangan Industri Pengecoran Logam Skala Besar dan Sedang yang Teraglomerasi terhadap Perubahan Koefisien Dasar Bangunan (KLB)

Berdasarkan kedua analisis tersebut dapat diketahui bahwa perkembangan industri pengecoran logam skala besar dan sedang yang teraglomerasi terhadap perubahan koefisien dasar bangunan (KDB) mendapat nilai 2, sementara perkembangan industri pengecoran logam skala besar dan sedang yang teraglomerasi terhadap perubahan koefisien lantai bangunan (KLB) mendapat nilai 3. Untuk mengetahui pengaruh perkembangan industri pengecoran logam skala besar dan sedang yang teraglomerasi terhadap perubahan intensitas lahan di wilayah penelitian langkah yang dilakukan adalah dengan menjumlahkan kedua nilai tersebut dan didapatkan nilai keseluruhan 5 . Selanjutnya menghitung nilai rata-ratanya dan di dapatkan nilai 2,5 , oleh sebab itu maka industri pengecoran logam skala besar dan sedang yang teraglomerasi berpengaruh tinggi terhadap perubahan intensitas lahan di wilayah penelitian sehingga mendapatkan nilai 3 .

- Pengaruh Perkembangan Industri Pengecoran Logam Skala Besar dan Sedang yang Teraglomerasi terhadap Pola Penggunaan Lahan di Wilayah Penelitian

Perkembangan industri pengecoran logam skala besar dan sedang yang teraglomerasi di wilayah penelitian masuk dalam perkembangan sedang sementara perubahan pola penggunaan lahan di wilayah penelitian masuk dalam perubahan rendah. Karena hubungan keduanya tidak berjalan lurus maka pengaruh antara perkembangan industri pengecoran logam skala besar dan sedang yang teraglomerasi terhadap perubahan pola penggunaan lahan termasuk kategori pengaruh sedang dan mendapat nilai 2. Pengaruh tersebut dapat terlihat pada perubahan lahan terbangun dan lahan tidak terbangun di wilayah penelitian, semakin banyak industri yang dibangun maka perubahan lahan dari lahan tidak terbangun menjadi lahan terbangun semakin tinggi. Pendapat lain menyatakan bahwa keberadaan industri telah mempengaruhi perubahan penggunaan lahan yang diakibatkan oleh adanya industri tersebut relatif tinggi, perubahan tersebut terjadi terhadap lahan non terbangun menjadi lahan terbangun. Kondisi prasarana jalan mengalami peningkatan kondisi yang baik, sementara ketersediaan fasilitas umum mengalami peningkatan sehingga fasilitas umum yang tersedia sudah memenuhi kebutuhan masyarakat (Sari dan Rahayu, 2014) yang menyatakan bahwa. Perkembangan industri menyebabkan pola penggunaan lahan di wilayah penelitian mengalami perubahan. Berikut merupakan peta pengaruh perkembangan industri pengecoran logam skala besar dan sedang terhadap perubahan pola penggunaan lahan 


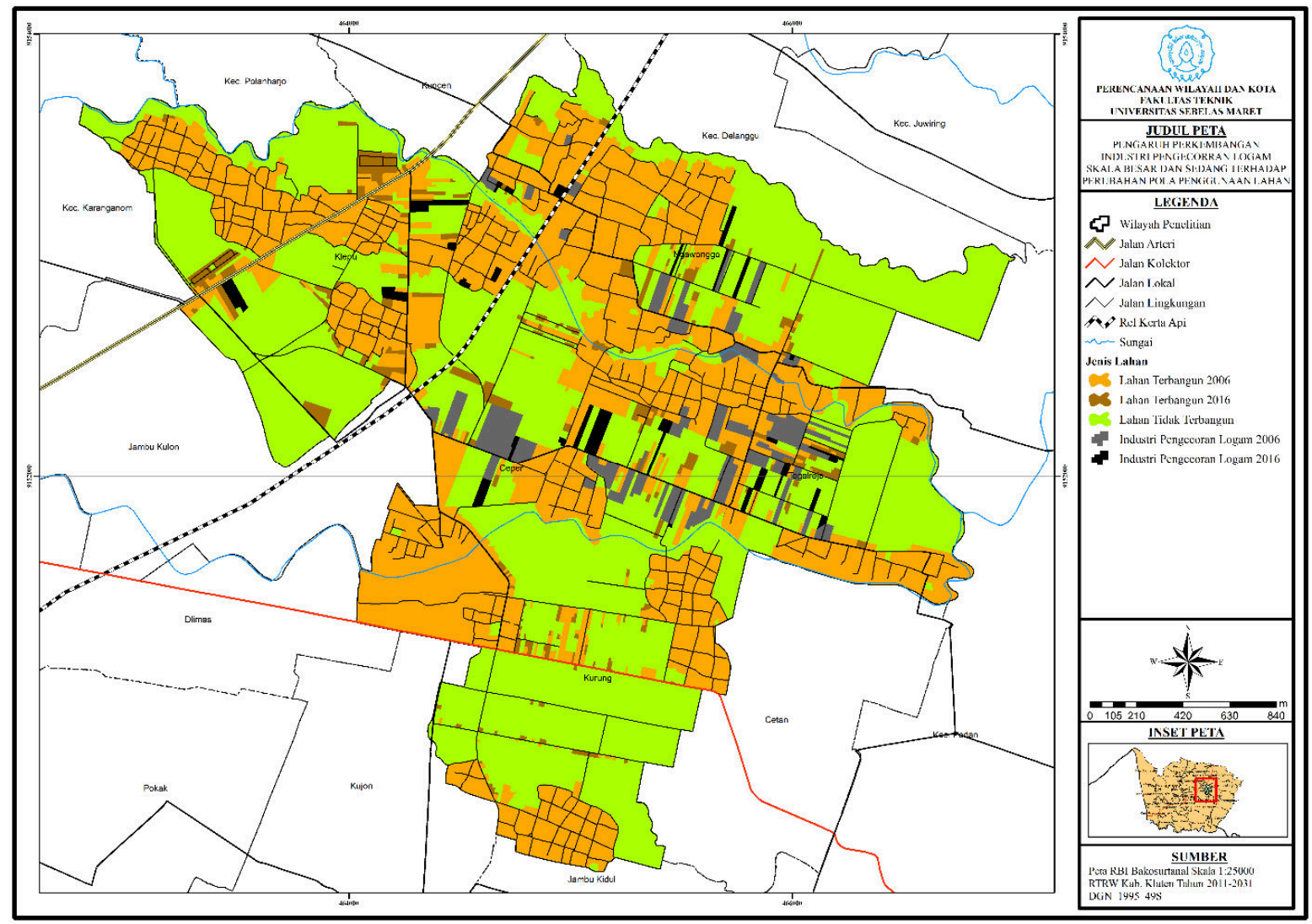

Sumber: Peneliti, 2017

Gambar 6. Peta Pengaruh Perkembangan Industri Pengecoran Logam Skala Besar dan Sedang yang Teraglomerasi terhadap Perubahan Pola Penggunaan

Pengaruh perkembangan industri pengecoran logam skala besar dan sedang yang teraglomerasi terhadap variabel perubahan guna lahan yaitu variabel perubahan jenis lahan, perubahan intensitas lahan serta perubahan pola penggunaan lahan didapatkan bahwa nilai pengaruh keseluruhan berjumlah 8.

Tabel 5. Analisis Perkembangan Industri Pengecoran Logam Skala Besar dan Sedang yang Teraglomerasi terhadap Perubahan Guna Lahan di Wilayah Penelitian

\begin{tabular}{|l|c|c|}
\hline \multicolumn{1}{|c|}{$\begin{array}{c}\text { Pengaruh Pengaruh Perkembangan Industri Pengecoran Logam Skala Besar dan Sedang } \\
\text { yang Teraglomerasi Terhadap Perubahan Guna Lahan }\end{array}$} & Pengaruh & $\begin{array}{c}\text { Nilai } \\
\text { Pengaruh }\end{array}$ \\
\hline $\begin{array}{l}\text { Pengaruh Perkembangan Industri Pengecoran Logam Skala Besar dan Sedang yang Teraglomerasi } \\
\text { terhadap Perubahan Jenis Lahan }\end{array}$ & $\begin{array}{c}\text { Pengaruh } \\
\text { Tinggi }\end{array}$ & 3 \\
\hline $\begin{array}{l}\text { Pengaruh Perkembangan Industri Pengecoran Logam Skala Besar dan Sedang yang Teraglomerasi } \\
\text { terhadap Perubahan Intensitas Lahan }\end{array}$ & $\begin{array}{c}\text { Pengaruh } \\
\text { Tinggi }\end{array}$ & 3 \\
\hline $\begin{array}{l}\text { Pengaruh Perkembangan Industri Pengecoran Logam Skala Besar dan Sedang yang Teraglomerasi } \\
\text { terhadap Perubahan Pola Penggunaan Lahan }\end{array}$ & $\begin{array}{c}\text { Pengaruh } \\
\text { Sedang }\end{array}$ & 2 \\
\hline & Jumlah & $\mathbf{8}$ \\
\hline
\end{tabular}

Sumber: Analisis Peneliti, 2017

Berdasarkan nilai pengaruh perkembangan industri pengecoran logam skala besar dan sedang yang teraglomerasi terhadap variabel perubahan guna lahan diatas selanjutnya dilakukan pencocokan nilai pengaruh dengan klasifikasi pengaruh variabel perkembangan industri pengecoran logam skala besar dan sedang yang teraglomerasi terhadap variabel perubahan guna lahan dan dapat disimpulkan bahwa perkembangan industri pengecoran logam skala besar dan sedang yang teraglomerasi berpengaruh tinggi terhadap perubahan guna lahan di wilayah penelitian.

\section{KESIMPULAN}

Perkembangan industri pengecoran logam skala besar dan sedang yang teraglomerasi di Kecamatan Ceper Kabupaten Klaten. Selama kurun waktu tahun 2006 hingga tahun 2016 perkembangan industri pengecoran logam skala 
besar dan sedang yang teraglomerasi di wilayah penelitian memiliki tiga aspek penelitian, yaitu peningkatan jumlah industri, peningkatan jumlah tenaga kerja serta peningkatan luas lahan industri. Berdasarkan peningkatan-peningkatan tersebut didapatkan bahwa industri pengecoran logam skala besar dan sedang yang teraglmoerasi di wilayah penelitian mengalami perkembangan sedang. Sementara perubahan guna lahan di wilayah penelitian berdasarkan analisis didapatkan bahwa perubahan jenis lahan mengalami perubahan sedang, perubahan intensitas lahan terdiri dari dua pembahasan yaitu perubahan koefisien dasar bangunan (KDB) serta perubahan koefisien lantai bangunan (KLB). Perubahan koefisien dasar bangunan (KDB) di wilayah penelitian mengalami perubahan rendah, sementara perubahan koefisien lantai bangunan (KLB) di wilayah penelitian mengalami perubahan sedang. Sementara perubahan pola penggunaan lahan di wilayah penelitian masuk dalam kategori acak.

Pengaruh perkembangan industri pengecoran logam skala besar dan sedang yang teraglomerasi terhadap perubahan guna lahan di Kecamatan Ceper Kabupaten Klaten. Selama kurun waktu 10 tahun perkembangan industri pengecoran logam skala besar dan sedang yang teraglomerasi berpengaruh besar terhadap perubahan guna lahan di wilayah penelitian. Perkembanagan industri yang ditandai dengan peningkatan jumlah industri, peningkatan jumlah tenaga kerja serta peningkatan luas lahan industri membuat guna lahan di wilayah penelitian mengalami perubahan yang ditandai dengan meningkatnya lahan terbangun baru yang menyebabkan berkurangnya lahan tidak terbangun baru. Seperti ditandai dengan bertambahnya lahan industri selain industri pengecoran logam skala besar dan sedang seperti industri tekstil, furniture maupun industri lainnya yang mendapatkan keuntungan aglomerasi dengan memanfaatkan fasilitas yang telah ada guna memenuhi kebutuhan operasional industrinya. Selain itu juga muncul industri pendukung aktivitas industri pengecoran logam seperti industri briket batu bara guna memenuhi kebutuhan bahan bakar industri pengecoran logam skala besar dan sedang di wilayah penelitian. Berdasarkan berbagai penjelasan diatas dapat disimpulkan bahwa perkembangan industri pengecoran logam skala besar dan sedang yang teraglomerasi berpengaruh terhadap perubahan guna lahan di wilayah penelitian. Hal tersebut dibuktikan dari pengaruh dari keduanya merupakan hubungan yang lurus antara perkembangan industri serta perubahan guna lahan. Hal tersebut juga sesuai dengan teori-teori yang menyatakan bahwa perkembangan industri akan mempengaruhi perubahan guna lahan di sekitarnya.

\section{DAFTAR PUSTAKA}

\section{Buku}

Baja, Sumbangan. (2012). Perencanaan Tata Guna Lahan Dalam Pengembangan Wilayah: Pendekatan Spasial Dan Aplikasinya. Yogyakarta: ANDI.

Djojodipuro, Marsudi. (1992). Teori Lokasi. Jakarta: Lembaga Penerbit Fakultas Ekonomi Universitas Indonesia.

Muta'ali, Lutfi. (2012). Daya Dukung Lingkungan Untuk Perencanaan Pembangunan Wilayah. Yogyakarta: Badan Penerbit Fakultas Geografi UGM.

Sugiyono. (2014). Metode Penelitian Kuantitatif Kualitatif dan $R \&$ D. Bandung: Alfabeta.

Yunus, Hadi Sabari. (1999). Struktur Tata Ruang Kota. Yogyakarta: Pustaka Pelajar.

\section{Jurnal yang diakses Online dengan nomor DOI atau URL}

Fatikawati, Yuliana Nur dan Mohammad Muktiali. (2015). Pengaruh Keberadaan Industri Gula Blora Terhadap Perubahan Penggunaan Lahan, Sosial Ekonomi Dan Lingkungan Di Desa Tinapan Dan Desa Kedungwungu. Jurnal Teknik PWK, 4 (3), 345-360. http://ejournal-s1.undip.ac.id/index.php/pwk/article/view/9084

Sari, Fittiara Aprilia dan Sri Rahayu. (2014). Kajian Dampak Keberadaan Industri PT. Korindo Ariabima Sari Di Kelurahan Mendawai, Kabupaten Kotawaringin Barat. Jurnal Teknik PWK, 3 (1), 106-116. Diakses dari http://ejournals1.undip.ac.id/index.php/pwk/article/view/4411

\section{Tesis/Disertasi yang Tidak Dipublikasi}

Abdullah. (2010). Pengaruh Perkembangan Industri Terhadap Pola Pemanfaatan Lahan Di Wilayah Kecamatan Bergas Kabupaten Semarang. Tesis, Universitas Diponegoro, Semarang.

Sunarjan Y.Y.F.R. (1991). Industri dan Perubahan Sosial Ekonomi Pedesaan Studi Kasus Masuknya Industri Rokok Kretek di Desa Gunung Lor, Kabupaten Kudus, Jawa Tengah. Tesis. Institut Pertanian Bogor, Bogor. 
Desa-Kota, Vol. 1, No. 1, 2019, 49-59

Times, 12/12/2005, p.4.

Dokumen Pemerintah yang Tersedia Online

Bakar, Sjofjan. (2006). Kelembagaan Pengendalian Pemanfaatan Ruang Di Daerah. Diakses dari

http://tataruang.bpn.go.id/bulletin/upload/data_artikel/Kelembagaan\%20Pengendalian \%20Pemanfaatan \%20Ruang\%20di\%2 ODaerah-Drs.Sjofjan\%20Bakar,MSc.PDF

Industri Skala Besar. (n.d.). Diakses November 22, 2016, dari website Badan Pusat Statistik, https://www.bps.go.id/Subjek/view/id/9

\section{Dokumen Pemerintah}

Badan Pusat Statistik Kabupaten Klaten. (2016, Juli 15). Kabupaten Klaten Dalam Angka Tahun 2016.

Kementerian Sekretariat Negara Republik Indonesia. (2014, Januari 15). Undang-Undang Nomor 3 Tahun 2014 Tentang Perindustrian. 